\title{
Brazil is getting older: demographic changes and epidemiological challenges
}

\author{
Envelhecimento populacional do Brasil: mudanças demográficas e desafios \\ epidemiológicos
}

\author{
Renato P. Veras*
}

\begin{abstract}
VERAS, R.P. Brazil is getting older: demographic changes and epidemiological challenges. Rev. Saúde públ., S. Paulo, 25 (6): 476-88, 1991. Population ageing is currently a phenomenon not only in developed countries but also in third world countries. In this paper the features of a population's ageing and the process of epidemiological transition are discussed along with the worldwide changes in age-structure. Population statistics in Brazil and the characteristics of the elderly population are presented and analysed in the light of recent changes. The Brazilian elderly population is also discussed, particularly the issues relating to the social cost of the aged populationt, its urban and rural distribution, the elderly by sex, marital status and level of schooling. and emphasis is given to the imbalance of the sexes and the consequences of it for women.
\end{abstract}

Keywords: Demographic aging. Demographic transition. Aged.

\section{Introduction}

A question which may arise in the minds of those reading this article, might be: Why write a paper on old people in a young country? A straight answer is simple: Brazil already has a large elderly population but very few studies have been undertaken on it. However, this is not the complete and best answer. The demographic data of the country have a lot of peculiarities that should be considered in greater depth.

The decline in fertility rates in Brazil in the last decade has had profound implications upon the demographic trend of its pyramid, and data show a growth in the number of elderly people. Despite the relative decrease in the number of children and an increase in the number of elderly, the proportion in the younger age group is still greater when compared with already aged countries. As a result, in Brazil, in the near future the demographic trend will be such that the proportion of the elderly population will remain less than $10 \%$ and will consist of a characteristically "young-old" group aged between 60 and 69 years. In many developed countries the fastest increasing age group is that with those over 70 years old $6,31,34,51,59.66,83$

Another of Brazil's peculiarities is that it is not

\footnotetext{
* Instituto de Medicina Social da Universidade do Estado do Rio de Janeiro- Rio de Janeiro, RJ - Brasil.

Separatas/Reprints - R.P. Veras - Rua São Francisco Xavier, 524, $7^{\circ}$ andar - 20550 - Rio de Janeiro, RJ Brasil.
}

homogeneous country. This can be expressed through a variety of indicators. With considerable regional variations, the coutry has areas of absolute poverty as well as developed industrialised regions. The national data only reflects the mean of that heterogeneity. The fertility and mortality rates for Brazil as a whole do not adequately reflect the increasing numbers of old people in the richer regions or the relative increase in numbers of old people in the poorest regions. Despite the fact that the number of aged is increasing in the country as a whole, there remains a significant variation between the proportion of elderly in these two kinds of areas. It is well known that no country is homogeneous. However, the dissimilarities between areas are not normally as enormous as in Brazil ${ }^{18.29 .49,55.57 .66,82}$.

In this paper demographic and economic data will be presented for the world as a whole and for Brazil. The characteristics of the ageing group as a whole, the concepts of a "young-old" group and the heterogeneity of Brazil will be explained in terms of age, sex, marital status, urban/rural distribuiton and literacy.

\section{Ageing and the world's elderly population}

\section{What is ageing?}

Old age is an imprecise term and the reality it conveys is difficult to perceive. When does one became old? At $50,60,65$ or at 70 year of age? Nothing fluctuates more than the contours of old age: that physiological, psychological and social 
complex. Is one as old as one's arteries, as one's brain, as one's heart, as one's morale or as one's civil status? Or is it the way other people come to regard that which classifies them as old?

It appears that it is not possible universally to standardise the concepts and terminology of ageing. Inevitably the concept has ideological and political overtones, and can best be viewed within individual societies*. Culturally defined, old age must be perceived differently in a country with an expectation of life at birth of 34 years from one in which the expectation of life at birth is of 77 years**, or in a city within which there are those who live in crowded shantytowns and others in luxurious houses. Despite awareness of this fact, in the interests of data comparability, a chronological approach will be used to define the elderly population. A cut-off-point of 60 is consistently employed in third world countries to define the elderly $1,3,11,20,29,43.58,60,66,69,74$ to $79,81,83$, and will be used in this study. In order to observe the differences between groups, three sub-groups will be used: 60 to 69 , a "young-old" group; 70 to 79 , a "middleold" group; and 80 and over, the "old-old" group***. In Brazil only the first two groups are numerically important (Table 1). Nowadays, particularly in the developed countries, the group over 80 is very much studied due to the high cost, the high risk and the great increase the in numbers of people involved $\mathrm{d}^{24,34.50,51}$.

Table 1. Population by age groups in Brazil, 1950 - 2025.

\begin{tabular}{rrrrrrr}
\hline Years & \multicolumn{5}{c}{ Population in millions by age groups } \\
\cline { 2 - 7 } & $0-14$ & $15-59$ & $60-69$ & $70-79$ & 80 more & Total \\
\hline 1950 & 21,696 & 27,928 & 1,451 & 545 & 209 & 51,944 \\
1960 & 29,912 & 36,849 & 2,190 & 850 & 290 & 70,191 \\
1970 & 39,131 & 49,108 & 3,007 & 1,225 & 485 & 93,139 \\
1980 & 45,461 & 66,197 & 4,475 & 2,147 & 593 & 119,003 \\
2000 & 56,988 & 108,147 & 8,229 & 4,620 & 1,503 & 179,487 \\
2025 & 60,571 & 151,356 & 19,673 & 10,537 & 3,672 & 245,809 \\
\hline
\end{tabular}

Source: Fundação IBGE ${ }^{17}, 1983$

* There are some reviews related to the history of old age, Laslett ${ }^{32}$, Covey ${ }^{9}$ and Minois ${ }^{45}$ provide valuable information on how ageing and the old were perceived in earlier times.

** The country cited with expectancy of life at birth of 34 years is Sierra Leone and those with one of 77 years are Japan and Sweden in Laslett ${ }^{31}, 1987$

*** Latin speaker use the expression Third Age to designate the aged. This expression has its origin in from the French title for les universités du Troisieme Age. Now the French are using the term fourth age for the age group over 80 years ${ }^{31.66}$.

\section{Demographic features of ageing}

Contrary to general belief, the main demographic feature of an ageing population is not the lengthening of the life span of its individuals, but the decrease in the fertility of its individuals.

The number of persons of 60 and over is largely determined by the number of births 60 to 80 years before the estimated date and the survival rate between birth and this older age. Because of general rises in the number of births, in the past years, and in survival rates in most countries, the number of elderly persons has been rising rapidly.

It is important to recognise that our future elderly population, at least for 60 years hence, has already been born. It is possible to trace the future impact of this birth cohort on the size of the older population long before they reach the age of 60 . For example, the large birth cohorts of 1945-1960, the post-world war baby boom, experienced by the majority of developed countries, will, under prevailing survival conditions, have a major impact on changes in the number of the elderly in the early part of the next century. If the conditions favorable to mortality continue to diminish, then the older population will enlarge to an even greater numbers than will be accounted for by the rise in birth cohorts. The decrease in mortality tends to contribute relatively little to the increase in the proportion of elderly persons as compared to the decrease in fertility and may in fact contribute to a decrease in the proportion of elderly persons. The effect of decreases in age-specific death rates on age structure depends upon the ages at which such decreases occur. If the decrease is the same at all ages, the age structure of the population will tend to remain the same. If death rates are high and the decrease in mortality is mainly in the younger age group, then the proportion of children and young people will tend to increase and the proportion of old people will tend to decrease. If, however, the mortality rate declines in the older group, as is expected to occur in the countries with lower mortality in future years, the proportion of older people will tend to increase.

\section{The epidemiologic transition}

A convenient summary index of mortality, which is commonly used for comparisons between and within countries, is life expectancy.

In England in 1870, the average life expectancy was only 26; almost haslf of the population was under 20 and less than a quarter were under ${ }^{42.45}$. Since the turn of the century in the United States, life expectancy at birth has increased from 47.0 , to 73.6 in $1980^{51}$. In Brazil the changes are even more 
impressive, since the expectancy of life for Brazilians has doubled during this century (Table 2 ). The cause of the rapid increase in life expectancy in this century was the substitution of the causes of death by heart disease and cancer for those previously caused by infectious and parasitic diseases. This shift in disease patterns has been described by $O \mathrm{mran}^{52}$ as the epidemiologic transition.

Table 2. Life expectancy at birth in both sexes, Brazil, $1900-2025$.

\begin{tabular}{cc}
\hline Years & Life expectancy at birth \\
\hline 1900 & 33.7 \\
1910 & 34.1 \\
1920 & 34.5 \\
1930 & 36.5 \\
1940 & 38.5 \\
1950 & 43.2 \\
1960 & 55.9 \\
1970 & 57.1 \\
1980 & 63.5 \\
2000 & 68.6 \\
2020 & 72.1 \\
2025 & 75.3 \\
\hline
\end{tabular}

Source: Santos ${ }^{62}, 1978$ (1900 - 1950)

UNO. DIESA ${ }^{69}$ (Periodical on Ageing), 1985 (1960 - 2025)

According to the theory of the epidemiologic transition, as nations modernise they tend to improve their social, economic, and health conditions. Life conditions that were previously conducive to the spread of infectious and parasitic diseases are rapidly replaced by more sanitary living conditions and improved medical technology. As the risk of dying from infectious diseases is reduced for a population, those saved from dying from such diseases survive into middle and older ages where they face the elevated risk of dying from degenerative or man-made diseases. Since degenerative diseases tend to kill at older ages more than infectious diseases, this transition in the causes of death is characterised generally by a redistribution of deaths from the young to the old. Conceptually, the theory of epidemiologic transition focuses on the complex changes in patterns of health and diseases and on the interactions between these patterns and their demographic, economic and sociologic determinants and consequences ${ }^{56}$. The epidemiologic transition theory was set in three stages, which represent a shift from high mortality/ high fertility to low mortality/low fertility. Omran distinguishes three major successive stages of the epidemiologic transition:

The age of pestilence and famine when mortality is high and fluctuating, thus precluding sustained population growth. In this stage the average life expectancy at birth is low and variable, lying somewhere between 20 and 40 years.
The age of receding pandemic when mortality declines progressively, and the rate of decline accelerates as epidemic peaks become less frequent: or disappear. During this stage, life expectancy at: birth increases to about 50 years of age. Population growth is sustained and begins to describe an exponential curve.

The age of degenerative and man-made diseases when mortality continues to decline and eventually approaches stability at a relatively low level. The resulting of longevity is a life expectancy for the population that extends beyond 70 years of life and is expected to change little in the future.

At the time when this theory was published it: was generally believed that the biological limit to life was approached in the seventh decade. Nowadays due to rapid declines in mortality rates for the major degenerative diseases a new stage has been described ${ }^{51}$. The fourth stage has been presented as:

The age of delayed degenerative disease when rapidly declining deaths rates are concentrated mostly at advanced ages and occur at nearly the same pace for males and females. The age pattern of mortality by cause remains largely the same as in the third stage, but the age distribution of deaths for degenerative causes are shifted progressively toward older ages. Another characteristic is the relatively rapidly improved survival, concentrated. among the population in advanced ages.

There is considerable conjecture and controversy regarding future morbidity patterns. Fries ${ }^{14}$ and Fries \& $\mathrm{Crapo}^{15}$ argues that there are biological constraints on human life. They forecast a continued decline in premature deaths and the emergence of a pattern of natural death at the end of a natural life span. Gruenberg ${ }^{22}$ and $\mathrm{Kramer}^{30}$ believe that as life expectancy is increased there will be a dramatic and catastrophic increase in the prevalence of mental disorders and chronic diseases in the elderly. Thomas ${ }^{65}$ has an optimistic view. He predicted that the major diseases of mankind will be cured and it is now possible to start thinking about human society relatively free of diseases. Manton' ${ }^{37}$ point of view is that the severity of chronic diseases will be gradually reduced resulting in reduced mortality rates and an increase in life expectancy.

As a result of this new stage of the epidemiologic transition, the older generation throughout the developed countries have achieved some remarkable declines in mortality and gains in life expectancy at advanced ages ${ }^{35,38}$. In the United States the mortality rate of the cohort age 80 years and above is decreasing faster than that of any other elderly age group. Their absolute numbers and the percentage of the population they represent are increasing at an astounding rate. It is expected that 
by the year 2040 , about $12,834,000$ adults in the United States will be 85 years of age or older ${ }^{24,61}$.

When a country has a great number of elderly people, attempts should be made to distinguish between the third and fourth stage of the epidemiologic transition. Brazil's situation, as in many less developed countries, is quite different, for instance in relation to the United States, because the fourth stage of ageing is not expected until the next few decades have passed. Consequently, over those next few decades Brazil will largely be a country with a large proportion of young people and young old ${ }^{73}$.

\section{Basic demographic trends in the world}

The problems associated with ageing populations are commonly regarded as of major significance only in developed countries where the demographic shift has occurred largely over the past century and has come to serious public notice over the past twenty years. But the global facts that have received little attention are that since the 1980 's more than half of all people reaching the age of 60 have been living in the Third World countries. By 2025 it is projected that three quarters of the world's aged population will be living in lesser developed countries (Table 3).

The prospects of an ageing society in the Third World are surprising. Table 4 illustrates the increase of elderly in a group of countries that are projected to have 16 million citizens of 60 years or older, in 2025. Brazil, Indonesia, Pakistan, Mexico, Nigeria

Table 3. The growih of the population aged 60 years and over, in the major regions of the world, 1980-2025.

\begin{tabular}{lrrrrr}
\hline \multirow{2}{*}{ Regions } & \multicolumn{2}{c}{$\begin{array}{c}\text { Elderly population } \\
\text { millions }\end{array}$} & \multicolumn{3}{c}{$\begin{array}{c}\text { Percentage total } \\
\text { population }\end{array}$} \\
\cline { 2 - 6 } & 1980 & 2000 & 2025 & 1980 & 2000 \\
\hline World & 371 & 595 & 1,135 & 8.3 & 9.7 \\
More developed & 173 & 234 & 329 & 15.2 & 18.3 \\
Less developed & 198 & 362 & 806 & 6.0 & 7.5 \\
regions & & & & & \\
Africa & 23 & 42 & 98 & 4.9 & 4.8 \\
Latin America & 23 & 42 & 96 & 6.4 & 7.6 \\
Brazil & 7 & 14 & 32 & 5.8 & 7.8 \\
Northern America & 39 & 47 & 82 & 15.4 & 15.7 \\
East Asia & 92 & 162 & 323 & 7.8 & 11.0 \\
South Asia & 74 & 142 & 321 & 5.3 & 6.8 \\
Europe & 82 & 102 & 131 & 16.9 & 19.8 \\
Oceania & 3 & 4 & 7 & 11.5 & 12.6 \\
\hline Note- Mor & & 4 &
\end{tabular}

Note - More developed regions include North America, Japan, all regions of Europe, Autralia-New Zealand and the Union of Soviet Socialist Republics.

Less developed regions include all regions of Africa, all regions of Latin America, China, Other East Asia, all regions of South Asia, Melanesia and MicronesiaPolynesia.

Source: UNO. DIESA ${ }^{69}$ (Periodical on Ageing), 1985.
Table 4. Projected increase in the population aged 60 years and over in the most populous countries, 1950 . 2025.

\begin{tabular}{lrrrrr}
\hline Regions & \multicolumn{3}{c}{$\begin{array}{c}\text { Population 60+ years } \\
\text { (millions) }\end{array}$} & \multicolumn{2}{c}{$\begin{array}{c}\text { Increase } \\
\text { (\%) }\end{array}$} \\
\cline { 2 - 6 } & \multicolumn{1}{c}{2025} & 2000 & 1975 & 1950 & $1950-2025$ \\
\hline China & 284.1 & 134.5 & 73.3 & 42.5 & 668.5 \\
India & 146.2 & 65.6 & 29.7 & 31.9 & 429.3 \\
USSR & 71.3 & 54.3 & 33.9 & 16.2 & 440.1 \\
USA & 67.3 & 40.1 & 31.6 & 18.5 & 363.8 \\
Japan & 33.1 & 26.4 & 13.0 & 6.4 & 517.2 \\
Brazil & 31.8 & 14.3 & 6.2 & 2.1 & 1514.3 \\
Indonesia & 31.2 & 14.9 & 6.8 & 3.8 & 821.1 \\
Pakistan & 18.1 & 6.9 & 3.6 & 3.3 & 548.5 \\
Mexico & 17.5 & 6.6 & 3.1 & 1.3 & 1346.2 \\
Bangladesh & 16.8 & 6.5 & 3.3 & 2.6 & 646.2 \\
Nigeria & 16.0 & 6.3 & 2.6 & 1.3 & 1230.8 \\
\hline Source: UNO. DIESA & (T) (The world ageing situation), 1985.
\end{tabular}

among others, will displace European counties from the ranking of countries with the largest numbers of old people. Brazil was the sixteenth, in the world ranking, in 1950 with 2.1 million elderly people, by 2025 it has been estimated that it will rank sisth with a staggering 31.8 million old people, with the largest proportional increase in the world over this period. In 75 years the Brazilian elderly population will have increased 15 times, whereas the population as a whole will increase only five fold ${ }^{26}$.

As ageing is a long term process and countries have different levels of fertility and mortality, it will take until 2075, according to the United Nations assumption ${ }^{21}$, for the age structure of most countries to stabilise and the differences between populations to disappear. The main assumptions are that the developed countries will maintain a fertility rate at replacement level, while less developed countries, in different periods, will get to that point later. As can been seen in Table 5, Latin American countries will achieve this level by the year 2030 .

Regarding mortality, the maximum projected life expectancy at birth for both sexes will be 76.7. This level will be reached, or very closely so, by all of the regions by 2075 (Table 6). Within the next century all regions will be similar as regards to age structure. It is important for the countries that are becoming old to learn from the process that has already occurred in developed countries and try to adapt to the phenomenon of a large number of people living longer.

\section{Brazil's demograhic trends}

Before describing some characteristics of the aged population, it is necessary not to lose sight of the complexities of this age group in a country like 
Table 5. Trends in fertility in the major regions of the world, 1975 - 2070.

\begin{tabular}{lccccc}
\hline & \multicolumn{5}{c}{ Gross reproduction rate } \\
\cline { 2 - 6 } Regions & $1975 /$ & $2000 /$ & $2020 /$ & $2040 /$ & $2060 /$ \\
& 1980 & 2010 & 2030 & 2050 & 2070 \\
\hline More developed & 0.99 & 1.02 & 1.01 & 1.01 & 1.01 \\
Less developed & 2.33 & 1.42 & 1.09 & 1.01 & 1.01 \\
Africa & 3.12 & 1.96 & 1.25 & 1.02 & 1.01 \\
Latin America & 2.40 & 1.47 & 1.02 & 1.01 & 1.01 \\
Northern America & 0.89 & 1.01 & 1.01 & 1.01 & 1.01 \\
East Asia & 1.47 & 1.01 & 1.01 & 1.01 & 1.01 \\
South Asia & 2.68 & 1.44 & 1.07 & 1.01 & 1.01 \\
Europe & 0.96 & 1.01 & 1.01 & 1.01 & 1.01 \\
Oceania & 1.38 & 1.17 & 1.04 & 1.01 & 1.01 \\
\hline
\end{tabular}

Note - More developed regions include North America, Japan, all regions of Europe, Australia-New Zealand and the Union of Soviet Socialist Republics.

Less developed regions include all region of Africa, all regions of Latin America, China, Other East Asia, all regions of South Asia, Melanesia and MicronesiaPolynesia.

Source: Grinblatt ${ }^{21} 1982$.

Table 6. Trends in mortality in the major regions of the world, $1950-2080$

\begin{tabular}{lllllll}
\hline & \multicolumn{5}{c}{ Life expectancy at birth } \\
\cline { 2 - 7 } Regions & 1950 & 1970 & 1990 & 2020 & 2040 & 2070 \\
& 1960 & 1975 & 2000 & 2030 & 2050 & 2080 \\
\hline More developed & 66.8 & 71.3 & 73.4 & 75.6 & 76.4 & 76.7 \\
Less developed & 44.1 & 52.8 & 62.0 & 70.8 & 73.9 & 76.1 \\
Africa & 38.6 & 46.4 & 56.7 & 68.0 & 72.3 & 75.6 \\
Latin America & 53.4 & 61.3 & 69.0 & 74.0 & 75.7 & 76.7 \\
Northern America & 69.4 & 71.4 & 74.1 & 75.8 & 76.6 & 76.7 \\
East Asia & 49.6 & 62.4 & 70.0 & 74.4 & 76.0 & 76.7 \\
South Asia & 40.8 & 49.0 & 59.8 & 70.2 & 73.5 & 76.1 \\
Europe & 66.7 & 71.2 & 74.0 & 76.0 & 76.5 & 76.7 \\
Oceania & 61.6 & 65.8 & 69.2 & 74.0 & 75.6 & 76.5 \\
\hline
\end{tabular}

Note - More developed regions include North America, Japan, all regions of Europe, Autralia-New Zealand and the Union of Soviet Socialist Republics.

Less developed regions include all regions of Africa, all regions of Latin America, China, Other East Asia, all regions of South Asia, Melanesia and MicronesiaPolynesia.

Source: Grinblat ${ }^{21}, 1982$.

Brazil. All the cohorts of survivors were somehow selected, economically, socially ethnically and so on, from the general population. Survivors are selected by certain characteristics, and this must be remembered in considering the data. Regrettably, the data analysis has been carried out on census figures collected in 1980. In order to use only the official data, all the statistics presented will be derived from FIBGE*. Fertility rates have declined

* FIBGE (Fundação Instituto Brasileiro de Geografia e Estatística) means Foundation of the Geographical and Statistical Institute of Brazil.
Table 7. Projection of demographic indicators in Brazil, $1980-2005$

\begin{tabular}{lrrr}
\hline Indicators & $1980-85$ & $1990-95$ & $2000-2005$ \\
\hline population(") & $120,564,000$ & $143,317,000$ & $170,815,000$ \\
annual births & $3,680,000$ & $3,580,000$ & $3,715,000$ \\
annual death & $1,150,000$ & $1,185,000$ & $1,325,000$ \\
annual growth & $2,530,000$ & $2,395,000$ & $2,390,000$ \\
crude birth rate & 30.05 & 24.18 & 21.50 \\
crude death rate & 9.03 & 7.17 & 7.49 \\
rate of growth & 2.10 & 1.64 & 1.40 \\
\hline
\end{tabular}

Note - (") Population in the middle of the period.

Source: Martine ${ }^{40}, 1989$.

sharply throughout the eighties and the census data in 1991 will show a different pattern**. The projection of FIBGE is more conservative than other studies ${ }^{7,40,48}$ in relation to the trend of the decrease in fertility. If the assumption made in Table 7, is the correct one, the size of the elderly population will be greater than that presented in this section.

\section{Profound political and economic changes in recent years}

Brazil has undergone profound and very rapid economic and political changes in recent decades. Between 1965 and 1980, the GNP grew at an average of $9 \%$ per annum and industrial production rose at an average of $10 \%$ per year ${ }^{81}$. However all of this development was achieved by very few people. There is an important political demension which must be considered. The Brazilian "economic miracle" was directed by an authoritarian and centralised military government. Brazil remained one of the most unequal societies in the world, and data show an increase in inequality. In $196010 \%$ of the population accounted for $39.6 \%$ of the total income, in 1970 it increased to $46.7 \%$ and in 1980 the richest $10 \%$ accounted for $51.0 \%$ of the total income ${ }^{18}$

With a population of 140 million, immense rivers and forests, rich agricultural lands, and huge deposits of gold, gems, petroleum and minerals, Brazil has the potential to become as wealthy as any nation on earth. With a gross domestic product of $\$ 350$ billion and annual exports of $\$ 34$ billion, despite all its diversities, it already has one of the ten strongest economies in the world.

But alongside that highly industrialized Brazil, lives another desperately poor country - and the gap that separates the two is wide. Seven out of ten Brazilians live in poverty; the very poor crowd into shantytowns and live on the edge of despair.

It is necessary to emphasise Brazil's

\footnotetext{
** In this decade the census will be carried out in 1991.
} 
heterogeneity because it gives rise to completely different patterns of society within different parts of Brazil. In view of the regional diversity, in order to gain a clearer understanding of the problem, data should be considered from each region. For instance, the indicator of life expectancy at birth for Brazil as a whole, shows an intermediate position in relation to the rest of the world, and better than that of many third world countries. However, data from the richer areas, such as Rio de Janeiro or São Paulo city, are almost the same as those of any developed country (Table 8). In order to cope with the increase in the elderly population these regional differences need to be taken into consideration.

Table 8. Life expectation at birth in both sexes for selected regions, countries, states and cities, 1980 . 1985.

\begin{tabular}{ll}
\hline More developed regions & 72.4 \\
Less developed regions & 57.0 \\
\hline \hline Chad & 43.0 \\
Bangladesh & 47.8 \\
Bolivia & 50.7 \\
India & 52.5 \\
Colombia & 63.6 \\
Philippines & 64.5 \\
\hline \hline Brazil & 63.5 \\
Paraíba & 46.7 \\
Maranhão & 57.4 \\
São Paulo & 69.4 \\
Rio de Janeiro & 69.7 \\
\hline \hline USSR & 70.0 \\
United Kingdom & 73.7 \\
United States & 73.9 \\
France & 74.5 \\
Switzerland & 75.9 \\
\hline Note Moredevepedregionsinclude &
\end{tabular}

Note - More developed regions include North America, Japan, all regions of Europe, Australia-New Zealand and the Union of Soviet Socialist Republics.

Less developed regions include all regions of Africa, all regions of Latin America, China, Other East Asia, all regions of South Asia, Melanesia and MicronesiaPolynesia.

Paraiba and Maranhão are states in the Northeast of Brazil.

Data for S. Paulo and Rio de Janeiro are for the respective cities.

Source: a. UNO. DIESA ${ }^{71}, 1982$

b. LSHTM ${ }^{33}, 1989$.

\section{Social cost of the aged population}

One crucial aspect that differentiates the ageing population in Brazil from that of developed countries is that Brazil still has a high proportion of its population in the 0-14 age group and this young group has its own particular social and medical needs, especially improvement in education and the banishment of common diseases. Parallel to this, the ageing population make new demands on health and social services. Elderly people's health problems are often of a chronic nature and may require costly interventions with complex technology. The projected growth in spending varies in each country. However the estimated mean is that the health cost of supporting one elderly person could cover three people of another age group ${ }^{59,78}$. The United States have estimated that per capita costs of the elderly are about 3 times those of young peoples aged less than 15 years, which means more than $\$ 4,000$ per years, per old person ${ }^{5}$, largely due to the fact that an elderly person is more likely to became sick and need costly medical treatment ${ }^{8,36,64}$. In Australia, government spending on the aged is 2.3 times greater than on the young ${ }^{23}$. For the government the problem is that while parents share the major economic burden of their dependent children with the government, the elderly are largely supported throught governmental expenditures alone.

Brazil is, nowadays, facing a particular situation. The needs of the old and the demands of the young are vying with each other for the scarce resources available in the country. In Western countries the competing demands are less dramatic. Younger age groups are smaller and the social infrastructure of education and health care services were consolidated long ago. Children's preventive and treatment services are of a good quality, at least when compared with those of poorer countries. In order to calculate the financial burden on the economically active within a society resulting from their support of their children and their elderly, we can use an indicator called the dependency ratio. This indicator provides a rough estimate of the cost to society of the "economically inactive" groups. The dependency ratio is usually defined as the ratio of the population under 15 and over 60 years to those between the ages of 15 and 60 inclusive. This indicator can be split into three indicators, one to measure the burden of the elderly, of the young, and of the elderly and young together.

The rise in the numbers of elderly people will be reflected in a higher aged-dependency ratio. The greater the younger population, the higher the youth-dependency ratio will be. In numerical terms the support burden on the working population is more accurately measured by the total dependency ratio, which takes account of the variations in numbers of children as well as in the number of elderly persons. However, it should be recognized that the financial burden of the elderly group is much higher thant the children and that the decrease in number of children does not, in economic terms, compensat for an and increase in the number of the 
elderly. In many already aged countries, it has been feared that over the next twenty to thirty years, the economically active workforce will not be able to provide a large enough tax base to support the dependent age groups, especially the elderly ${ }^{54}$.

Brazil is a good example of a country whose total dependency ratio is not increasing (Table 9). On the contrary, the increase in the over 60's is counterbalanced by a decrease in the 0-14 years group. But when the dependency ratio is calculated separately for the elderly and children, it is seen that ratio for the over 60's has increased sharply, which means a high financial $\cos ^{69,74,78}$. The conventional wisdom is that the family and community generally should accept much more responsibility for their aged members. However this is undergoing change as society itself changes the traditional loyalties and relationships between the generations.

Table 9. Estimated and projected dependency ratios in Brazil, 1960 - 2025.

\begin{tabular}{lrrrrr}
\hline Age Group & 1960 & 1980 & 2000 & 2020 & 2025 \\
\hline $0-14$ years & 84 & 67 & 53 & 41 & 40 \\
60 or more & 9 & 11 & 13 & 20 & 22 \\
\hline Total & 93 & 78 & 66 & 61 & 62 \\
\hline
\end{tabular}

Note - Dependency ratio can be divided into three measures: Total-dependency ratio, Child-dependency ratio and Aged-dependency ratio. Total-dependency ratio is a measure of the number of persons aged 0 to 14 and 60 or over per 100 persons of working age (15 to 59 years); Child-dependency ratio is a measure of the number of persons aged 0 to 14 per 100 persons of working age (15 to 59 years); Aged-dependency ratio is a measure of the number of persons aged 60 or over per 100 persons of working age (15 to 59 years).

Source: UNO. DIESA ${ }^{69}$, (Periodical on Ageing), 1985.

\section{Some characteristics of the urban/rural distribution}

As the economy has changed over the last 40 years, so the geographical distribution of the Brazilian population has also shifted. With industrialisation, there has been major rural-urban migration and most of the population now lives in cities $^{27}$. The projection highlights an increasing urbanisation (Figure 1).

From 1965 to 1980 the share of agriculture declined from $19 \%$ to $11 \%$ of the GNP and the percentage of the labour force working in agriculture fell from $49 \%$ to $31 \%^{82}$. These demographic changes have important social and economic consequences for the population as a whole and particularly for the aged ${ }^{29,58,78}$. Brazil is now an urban society and most elderly people live in large cities. In fact the proportion of elderly people has always been greater in the urban areas, and this trend is even more marked for womem
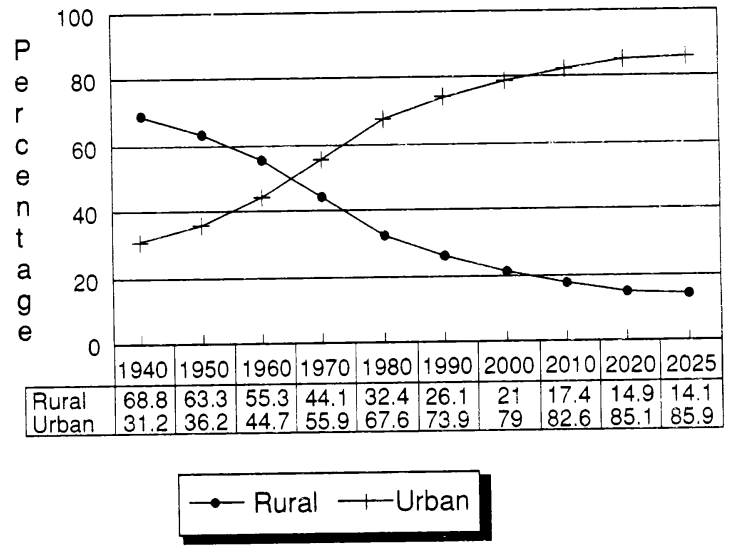

Source: Fundação IBGE ${ }^{16}, 1981$ (1940 - 1980)

Fundação IBGE/CELADE ${ }^{19}, 1987$ (1990 - 2025)

Figure 1. Rural and urban population in Brazil, 1940 2025.

than men, reflecting the predicted pattern of lower urban mortality of women. This might be the result of a lower feminine mortality associated with a lower urban mortality ${ }^{3}$ (Table 10). Most Latin American countries are observing an intense migration towards the larger cities, contradicting the widely held belief that in the Third World most of the aged population lives in rural areas ${ }^{49,66.83}$. In Brazil, a growing proportion of them live in the urban areas. This situation makes Brazil, in relation to the distribution of its aged population, similar to the developed countries ${ }^{72}$. The Brazilian pattern of rural-urban migration is distinct from other Third World countries and in particular from African and South Asian countries ${ }^{68}$. There, the migrants leave their villages with the intention of returning. In Pakistan, the small land owner, during periods of agricultural crisis, moves to urban areas leaving his small plot of land with a view to the possibility of his return in of Pakistan peasants, who have left to work in Arab countries, invest their economies in their rural areas where they will eventually return ${ }^{28}$.

Brazil, Singapore, Mexico and Korea, third

Table 10. Percentage of urban population by age group and sex in Brazil, 1950 - 1980.

\begin{tabular}{cccccccc}
\hline & \multicolumn{2}{c}{ both sexes } & \multicolumn{2}{c}{ men } & \multicolumn{2}{c}{ women } \\
\cline { 2 - 7 } years & all ages & $\begin{array}{l}60 \text { or } \\
\text { more }\end{array}$ & all ages & $\begin{array}{c}60 \text { or } \\
\text { more }\end{array}$ & & $\begin{array}{r}60 \text { or } \\
\text { more }\end{array}$ \\
\hline 1950 & 36.2 & 42.0 & 34.7 & 39.2 & 37.6 & 48.0 \\
1960 & 44.9 & 51.6 & 43.3 & 45.9 & 46.5 & 55.8 \\
1970 & 55.9 & 61.3 & 54.4 & 57.2 & 58.0 & 65.3 \\
1980 & 67.6 & 70.0 & 66.3 & 65.5 & 68.8 & 73.2 \\
\hline
\end{tabular}

Source: Fundação IBGE ${ }^{17}, 1983$. 
world countries characterized by aggressive capitalist expansion, have a permanent and mainly unidirectional flow of rural migrants to the cities.

In Brazil the main motives for migration are rural unemployment, lower rural salaries and the scanty rural infrastructure of the public services. Television and radio have played an important role in projecting the illusive glamor of better life in the cities. Rural land ownership has increasingly been concentrated in the hands of a wealthy few who have invested in the mechanisation of farming, improving production but adding to rural unemployment, again echoing the familiar historical story of industrial urban growth in Europe and the Unite States ${ }^{4}$.

\section{Distribution of the population by age and sex}

As in many countries, Brazilian elderly women outnumber men. As life expectancy has increased, the differential life expectancy between men and women has widened. Data for women show that Brazilian females live 5 years longer than males (Table 11) and this tendency is expected to continue and increase with time due to the patterns of male mortality (see Figure 2). As can be seen in Table 12 , when the last three decades are analyzed, the difference between the proportion of women in relation to men, was found to increase with age. In 1970 the group above 60 had $5.4 \%$ more women than men; above 70 years the difference increased to $16.9 \%$ and in the group above 80 it reached

Table 11. Life expectancy, male and female in Brazil, 1980 - 2025.

\begin{tabular}{ccccc}
\hline \multirow{2}{*}{ Pediod } & \multirow{2}{*}{ sex } & \multicolumn{3}{c}{ Life expectancy } \\
\cline { 3 - 5 } & & at bith & 60 years & 70 years \\
\hline $1980-1985$ & men & 61.0 & 17.7 & 11.4 \\
& women & 66.0 & 18.9 & 12.2 \\
$1995-2000$ & men & 64.7 & 18.2 & 11.7 \\
& women & 70.4 & 20.3 & 13.2 \\
$2020-2025$ & men & 69.0 & 18.7 & 12.1 \\
& women & 75.3 & 21.8 & 14.3 \\
\hline
\end{tabular}

Source: Fundação IBGE/CELADE ${ }^{19}, 1984$,

Table 12. Sex ratios for three aged groups in Brazil, 1960 $-1980$.

\begin{tabular}{|c|c|c|c|}
\hline \multicolumn{2}{|c|}{60 years or more } & 70 years or more & 80 years or more \\
\hline 1960 & 101.6 & 114.9 & 157.4 \\
\hline 1970 & 105.4 & 116.9 & 144.9 \\
\hline 1980 & 111.5 & 120.5 & 168.20 \\
\hline
\end{tabular}

Note - Sex ratios means the number of women per 100 men Source: Fundação IBGE ${ }^{17}, 1983$.

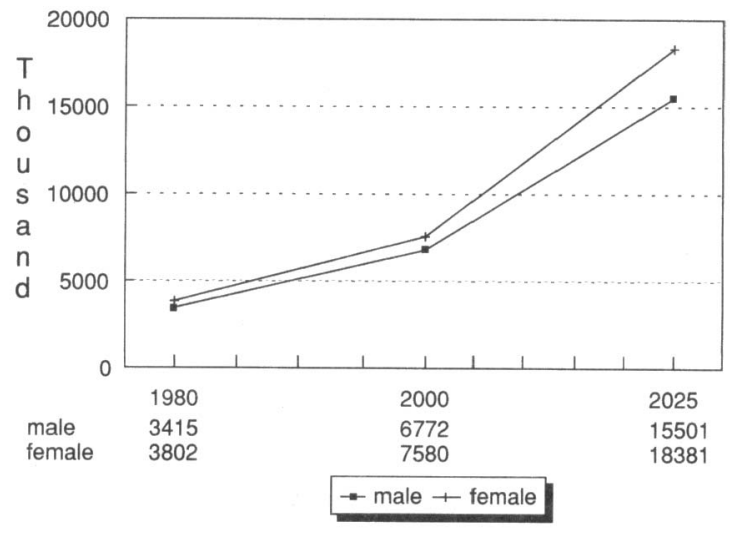

Source: Fundação IBGE/CELADE ${ }^{19}, 1984$.

Figure 2. Estimated and projected numbers of aged by sex in Brazil, 1950 - 2025.

$44.9 \%$. The differences increased sharply for those women of 80 years or more, the surplus of whom was of $44.9 \%$ in 1970 , but of $68.2 \%$ in 1980 . In relation to the sex distribution of older people, Brazil has the same pattern as already aged countries $^{63}$. The plethora of the female proportion at the older ages results from the continuing divergence of male and female death ratios, i.e., an increase in the excess of male mortality in relation to female mortality, at these and younger ages. Several hypotheses have been offered in the attempt to explain the longer life of women in Brazil, in addition to the usual genetic, biological explanations:

- Difference of risk exposure - Brazil has a bad record of accidents at work. According to a survey conducted in 1972, one in five of the working population suffered injuries at work ${ }^{46}$. Accidents at work leading death, mainly be fall men. Home and work accidents, traffic accidents, homicide and suicide are together four times more frequent in men than women, in Brazilian urban areas. There the death ratio of the above shows a ratio of 94.5 for men and 23.8 for women in a population of $100,000^{44}$. These causes of death are only exceeded cardiovascular and neoplasm deaths. In Rio de Janeiro these "external" violent and accidental deaths are the second most common cause of death, cardiovascular disease being the first.

- Differences in consumption of tobacco and alcohol - In the 1980's, deaths due to cardiovascular disease and neoplasms exceeded those by infectious and parasitic diseases, as the main causes of death, in Brazil. Men are also more likely to smoke and to drink heavily and these products are well-established risk factors, associated with the two most important causes of death in the over 45 age group.

- Differences in the attitude towards sickness - 
The better facilities of the Brazilian Health Care System are concentrated in large urban centres, and due to the urbanization process more and more people nowadays have access to physicians and hospitals. Women in general are more aware of symptoms, have a better knowledge of disease and make greater use of health services than men ${ }^{67}$. It is possible that early detection and better care of chronic disease in women contribute to a better prognosis.

- Medical obstetric care - Perinatal mortality, formerly one of the main causes of early death in women, is currently low. There has been a major expansion of medical care to women during and after child birth.

\section{The aged according to marital status}

The distribution by sex, age and marital status in Brazil follows the international tendencies ${ }^{62}$. There are pronounced differences in the marital distribution of the population at older ages, both between the sexes and between the age groups.

Brazil, as many other countries, has a pattern which shows that the vast majority of men and women get married at some time during their lives. Here the mean age of marriage is $\mathbf{2 2 . 9}$ for women and 26 for men ${ }^{20,41}$.

Although getting marriage after 60 years of age is not common, the majority of marriages occurring at that age releate to men. This happens not only with those who become widowers, but also with single people. In 1980 about 17,000 men of 60 years or more got legally married, and 11,000 of them had not previously been married. Among women the figures are smaller; 5,000 married, and of those only 500 were windows. The chances of being widowed increase with age (Table 13), and women have smaller chances of marrying a younger spouse. The remarriage of widowers is more frequent than the remarriage of widows. The 1980 census shows that there were only $9 \%$ of couples in which the woman was older than the man. There are some studies that say that the mortality rates vary according to marital status: married men and women have lower death rates, and divorced men and women have higher death rates, than single and widowed men and women ${ }^{13,47}$. These data suggest that companionship during later life is a positive factor for prolonging life. There can be little doubt that infra-family relationships have been undergoing significant changes. The last census showed a large proportion of elderly people living alone. This is particulary true for women who represented $72 \%$ of the elderly living alone ${ }^{2}$. Due to the much higher mortality rates of men than women, the higher remarriage rates of older men rather than
Table 13. Percentage of marital status by sex and age groups in Brazil, 1980.

\begin{tabular}{lcccccc}
\hline \multicolumn{2}{l}{ Aged group by sex } & single & divorced & widowed & married \\
\hline \hline 60 to 64 & men & 5.2 & 2.9 & 6.2 & 84.2 \\
\cline { 2 - 6 } & women & 8.4 & 5.2 & 30.5 & 53.6 \\
\hline \hline 65 to 69 & men & 5.3 & 3.2 & 9.5 & 80.6 \\
\cline { 2 - 6 } & women & 8.9 & 4.5 & 41.3 & 42.9 \\
\hline \hline 70 and over & men & 5.2 & 2.8 & 20.3 & 69.9 \\
\cline { 2 - 6 } & women & 9.5 & 2.6 & 61.5 & 23.0 \\
\hline
\end{tabular}

Note - Figures may yield correct totals because there is no information available on $1.6 \%$ of men and $2.8 \%$ of women.

Source: Fundação IBGE'17, 1983.

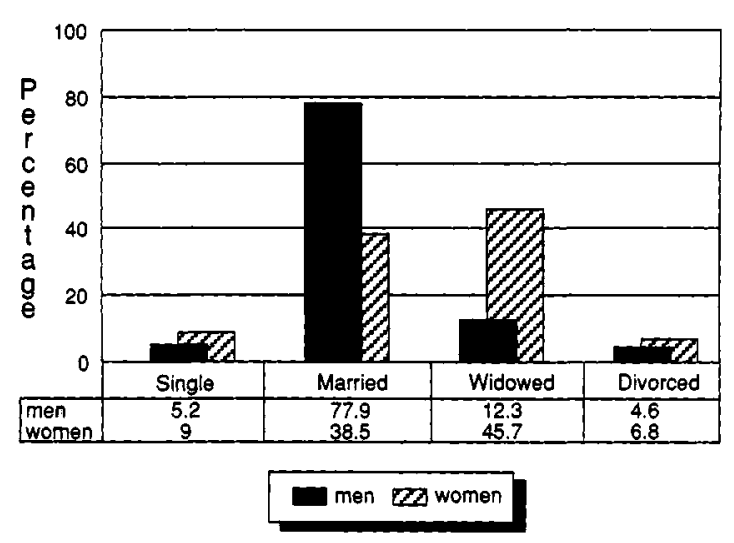

Source: Fundação IBGE ${ }^{16}, 1981$.

Figure 3. Sex differences in marital status of the elderly in Brazil, 1980.

older women and the tendency of men to marry younger women, all result in a higher proportion of elderly women living without a companion. Together these differences account for the large majority of widows in the age group over 60 (Figure $3)$.

\section{Economic situation among the elderly}

Poverty is a further bitter characteristic of old age. Despite the heterogeneity of the aged, there are a number of reasonable and consistent similarities, one of which is that the elderly are generally less well-off economically than the other adults in the population.

This fact is closely related to the changes society has undergone. In Brazil the intensive process of urbanization and industrialization over the last decades has had greater consequences for the older generation. The proportion of the elderly not economically active is increasing with the passing of the decades. In Brazil, in 1950, $83 \%$ of men were aged between 60 and 69 inclusive, and $57 \%$ of 70 years or more were activelly employed. In 
Table 14. Percentage of working population over 60 years by area, and age group in Brazil, 1980.

\begin{tabular}{ccccc}
\hline Aged group & area & men & women & Total \\
\hline 60 to 69 & total & 57.5 & 10.3 & 33.2 \\
& urban & 48.9 & 10.0 & 27.9 \\
70 and over & rural & 73.5 & 11.2 & 45.0 \\
& & & & \\
& total & 21.8 & 2.8 & 11.4 \\
& urban & 15.9 & 2.5 & 8.2 \\
& rural & 32.8 & 3.8 & 19.1 \\
\hline
\end{tabular}

Source: Fundação IBGE ${ }^{17}, 1983$.

1980 the rates decreased to $57 \%$ and $22 \%$, repectively. For women, who always had less economic involvement, the decrease has also occurred and in 1980 (Table 14) there were only $10 \%$ and $2 \%$ of women, in the same age groups, working.

There are three reasons for this reduction that need to be considered. Firstly, better social security care for the elderly population*, particularly in the rural areas. Secondly, the decrease of agricultural activity, due to the rural exodus and the growth of industrialization, and thirdly, the generally lower levels of qualification amongst elderly people as compared to the younger generation, which exclude them from the better-paid work-market. In the past the status and prestige of the aged were high. However, there is no doubt that there have been considerable changes in recent years. Nowadays the elderly are increasingly unwanted by their families, stereotyped and categorized as socially useless. This discrimination of old age has been condemned as an infringement of the right to work. Their wisdom and experience accumulated over many years is undervalued and under-used.

There is an increasing dismissal of older people from the modern work-place due to the rapid change of labor requirements as a result of the frenzied modernization of industry. In S. Paulo a study has revealed that the only group in which unemployment was increasing rapidly was among older workers, because employers preferred the greater physical potential of the younger worker ${ }^{66}$. The old man, after a certain age, no longer finds work; nobody wants to give him work. The problem of the unskilled worker is that when he/she passes 40 years of age, he/she can expect to be discriminated against because of his/her "ageing". For each unqualified person there are many more younger people seeking the same job.

In general, the Third World countries in Asia ${ }^{20,23,39}$ still have a greater number of elderly people in their work force, much greater than that in Brazil. This is because, particularly non-

* Despite the indicalously low pension paid: no more than 20 pounds monthly. mechanised, agricultural activities still exist, and employ a large number of old people.

In Brazil, the 1980 census showed that 1.8 million people over 60 years of age were employed; 1.52 million were men and 280 thousand were women. In relation to the agricultural sector there is an important reduction to be noted when comparing data for 1950 with those for 1980 . In the 50's the agricultural and cattle sector employed $72 \%$ of old men but in the 80's this figure had been reduced to $57 \%$. Another characteristic of the urbanization process was that the only activities which showed relative increases in the number of elderly people employed were those relating to small businesses or self-employment. Again the majority of old people engaged in these activities were men. There is no doubt that women suffer more than men in obtaining work in later years. The possibility of finding paid jobs, despite there being no legal constraints, is rather small. The greatest problem for the older person without a pension or recourse to social security recourse is undoubtedly that he or she has to work to live.

Traditionally the welfare of the aged population has been provided within the framework of the extended family relationship. However, in Brazil the extended family ratio is declining, and there is some evidence that the traditional support systems are being eroded by social changes ${ }^{3}$, and futhermore, the social security program is extremely meagre and limited in its size, duration and coverage. As a consequence of the current way of life, the aged have to cope with the financial costs of living. Those who have not saved during their productive life experiense, in general, a worse economic situation, since after retirement their pensions are smaller than their previous salaries.

\section{Schooling among the elderly}

Although decreasing, the rate of illiteracy in Brazil is still high: $32 \%$ of the population over 5 years old are illiterate. The 1940 census figures show that only $50 \%$ of men and $38 \%$ of women above 10 years old or more were literate. In the age group between 20 and 39 years this proportion shows a substantial increase due to a low literacy rate among the elderly. In the four subsequent decades there was a significant improvement in relation to literacy. In 1980, the percentage of the literate population over 10 years old was $75 \%$ for Brazil as a whole and about $90 \%$ for Rio de Janeiro and S. Paulo. However this is not a satisfactory figure, particularly if it aggregates the information, showing that many of those considered literate had only a few years of formal education; $60 \%$ completed primary school and only $16 \%$ finished 
'Table 15. Percentage of literate population over five years old, by sex and age in Brazil, 1950 - 1980.

\begin{tabular}{lccc}
\hline \multirow{2}{*}{ years } & all ages & 60 to 69 & 70 or more \\
\cline { 2 - 4 } & \multicolumn{3}{c}{ both sexes } \\
\hline 1950 & 42.7 & 39.3 & 32.8 \\
1970 & 60.3 & 49.3 & 41.7 \\
1980 & 68.0 & 52.7 & 43.7 \\
\hline \hline & \multicolumn{4}{c}{ men } \\
1950 & 46.0 & 48.0 & 41.0 \\
1970 & 62.0 & 57.0 & 49.5 \\
1980 & 68.6 & 58.8 & 50.3 \\
\hline \hline \multicolumn{4}{c}{} \\
1950 & 39.3 & 30.4 \\
1970 & 58.7 & 41.4 & 26.4 \\
1980 & 67.3 & 47.0 & 35.1 \\
\hline
\end{tabular}

Source: Fundação IBGE ${ }^{17}, 1983$.

secondary school ${ }^{20}$. Concerning the elderly (Table $15)$, there are clear differences between the sexes and between age groups. With the elderly, the same pattern of few years of formal education occurs. In $1980,50.3 \%$ of men at the age of 70 years and over, knew how to read and write, but only $50.4 \%$ had finished primary school ${ }^{3}$. Another finding is that in the developed cities, such as S. Paulo, Rio de Janeiro and Porto Alegre, the rate of literacy is higher than the national mean. This is so among the elderly population. In these areas, about $80 \%$ of men and $60 \%$ of women are literate. However, in the suburbs of those cities, only a few miles away, the proportion of literacy is reduced to $60 \%$ and $40 \%$, repectively. The literacy differential between sexes among the elderly population can be understood as a reflection of the social organization in Brazil at the beginning of this century, when education was restricted to the elite and available much more easily to men than to women. This characteristic of society 60 or 70 years ago is now leaving the elder women in an inferior position as regards coping with the difficulties of old age in a country with few facilities.

\section{Reflections on the sex imbalance}

There are many implications of the sex imbalance. An older woman is commonly associated with widowhood, reduced income, increased poverty and a greater risk of ill health and institutionalization. To this showed be added the problems of loneliness of single, older women. In Rio de Janeiro, it has been found that one of the most significant social problems of the older woman is loneliness, poverty and social deprivation particularly among older widows and unmarried women who live on their own and often rely on charity to survive. The triad of poverty, loneliness and sickness are commonly related to elderly women $^{10,25,80}$. Some authors have described this even more drastically, and the older female is embodied in the words "quadruple jeopardy"*53. However, as was correctly pointed out by Dressel ${ }^{12}$, the argument for the feminization of poverty, in isolation, has the potential for distorting and simplifying the issue. The socio-inequalities are not divided into gender, but into social class and race. As a result, workingclass and racial-ethnic group members, male and female alike, are more susceptible to the experience of unemployment, underemployment, and unstable low-wage employment than are their white-collar and white counterparts. In sum, social class and race are primary stratifiers of people's lives, as is gender. As with most "minority" groups in the population, the elderly have a different status from other age groups, and this is also true as between men and women. The elderly women only reflect the society's stratification of and discrimination against them.

VERAS, R.P. Envelhecimento populacional do Brasil: mudanças demográficas e desafios epidemiológicos. Rev. Saúde públ., S. Paulo, 25: 476-88, 1991. O crescimento da população idosa é um fenômeno que ocorre nos países centrais, mas também, de modo crescente, nos países do Terceiro Mundo. Este artigo apresenta os motivos deste crescimento, discute o processo de transição epidemiológica, as mudanças na estrutura etária da população idosa em todo o mundo, e em particular no Brasil. Estatísticas da população brasileira e as características do idoso brasileiro são apresentadas e analisadas em função das mudanças ocorridas recentemente. $\mathrm{O}$ artigo aborda vários tópicos relacionados com o idoso brasileiro: o custo financeiro para a sociedade manter uma população idosa, a distribuição urbana e rural, a diferença numérica entre sexos, o estado conjugal, a escolaridade, entre outros. Ênfase é conferida a algumas características e particularidades da mulher idosa.

Descritores: Envelhecimento da população. Transição demográfica. Idosos.

\section{References}

1. ANZOLA-PEREZ, E. Ageing in Latin American and the Caribbean. In: Pan American Health Organization. Toward the well-being of the elderly. Washington, D.C., 1985. p. 9-23. (Scientific Publication, 492).

2. BERQUÓ, E.S. \& CAZENAGHI, S.M. Oportunidades e fatalidades: um estudo demográfico das pessoas que moram sozinhas. In: Encontro Nacional de Estudos Populacionais, 6oㅡ, Olinda, PE, 1988. Anais. Belo Horizonte, Associação Brasileira de Estudos Populacionais, 1988. v. 1, p. 155-81.

\footnotetext{
* Which means, to be old, poor, female and of a minority
} status. 
3. BERQUÓ, E.S. \& MOTTA LEITE, V. Algumas considerações sobre a demografia da população idosa no Brasil. Cient. Cult., 40: 679-88, 1988.

4. BILSBORROW, R.E. et al. Migration surveys in low income countries: guidelines for survey and questionnaire design. London, Croom Helmn, 1980.

5. BRODY, J.A. Changing, health needs of the ageing population. In: Research and the ageing population. Chichester, John Wiley, 1988. p. 208-20.

6. BUTLER, R.N. \& BEARN, A.G., ed. The aging process: therapeutic implications. New York, Raven Press, 1984.

7. CAMARANO, A.A. et al. Século XXI: a quantas andará e onde estará a população brasileira. Brasília, IPEA, 1988. [Unpublished].

8. CLARK, R.L. \& SPENGLER, J.J. The economics of individual and population aging. New York, Cambridge University Press, 1980.

9. COVEY, H.C. Old age portrayed by the ages-of-life models from the middle ages to the $16^{\text {th }}$ century. Gerontologist, 29: 692-8, 1989 .

10. CREECY, R.F. et al. Loneliness among the elderly: a causal approach. J. Gerontol., 40: 487-93, 1985.

11. CUNHA, U.G.V. et al. Levantamento epidemiológico psicogeriátrico em asilos. $J$. bras. Psiquit., 34: 389-94, 1985.

12. DRESSEL, P.L. Gender, race, and class: beyond the feminization of poverty in later life. Gerontologist, 28: 177 . $80,1988$.

13. FOSTER, D. et al. Male longevity and age differences between spouses. J. Gerontol., 39: 117-20, 1984.

14. FRIES, J.F. Aging, natural death and the compression of mortality. N. Engl.J. Med., 303: 130-5, 1980.

15. FRIES, J.F. \& CRAPO, L.M. Vitality and aging: implications of the rectangular curve. San Francisco, WH Freeman, 1981.

16. FUNDAÇ̃̃O IBGE. Anuário estatístico do Brasil: 1981. Rio de Janeiro, 1982. v. 42

17. FUNDAÇĀO IBGE. Anuário estatístico do Brasil: 1983. Rio de Janeiro, 1984. v. 44

18. FUNDAÇĀO IBGE. Estatísticas históricas do Brasili séries econômicas, demograficas e sociais 1950 a 1988; $2^{\mathrm{a}}$ edição revisada e ampliada. Rio de Janeiro, 1990. (Séries Estatísticas Retrospectivas, v. 3)

19. FUNDAÇÃO IBGE/CELADE. Brasil: estimaciones y projecciones de poblacion 1950-2025. Santiago, Chile, 1984.

20. FUNDAÇÃO SEADE. O idoso na Grande Sāo Paulo. São Paulo, 1990. (Coleção Realidade Paulista).

21. GRINBLAT, J. Aging in the world: demographic determinants, past and long-term perspective to 2075. Wld Hlth Statist. Quart., 35: 124-32, 1982.

22. GRUENBERG, E.M. The faitures of success. Milbank Mem. F. Quart. Hlth and Soc., 55: 3-24, 1977.

23. HUGO, G. Population ageing: some demographic issues in developing countries. [Background paper prepared for Session VI of the program for developing country participants, International Congress of Gerontology, New York, 1985].

24. JETTE, A.M. \& BOTTOMLEY, J.M. The graying of America: opportunities for physical therapy. Phys. Ther., 67: 1537 $42,1987$.

25. JONES, D.A. et al. The problem of loneliness in the elderly in the community: characteristics of those who are lonely and the factors related to loneliness. J. roy. Coll. Gen. Practit., 35: 136-9, 1985.

26. KALACHE, A. Ageing everywhere: the new reality. THS, 6 May, 1986.

27. KALACHE, A. Ageing in developing countries. In: Principles and practice of geriatric medicine. Chichester, John Wiley, 1991. p. 1517-28.

28. KALACHE, A. Ageing in Pakistan; Report of Workshop. Copenhagen, World Health Organization, 1986.

29. KALACHE, A. et al. O envelhecimento da população mundi- al; um desafio novo. Rev. Saúde públ., S. Paulo, 21: 200-10 1987.

30. KRAMER, M. The rising pandemic of mental disorders and associated chronic diseases disorders. Acta Psych. Scand. 62 (Suppl. 285): 1980.

31. LASLETT, P. The emergence of the third age. Ageing and Soc., 7: $133-60,1987$

32. LASLETT, P., ed. The history of ageing and the aged. Cambridge, Cambridge University Press, 1977.

33. LONDON SCHOOL OF HYGIENE AND TROPICAL MEDICINE Programme on the Public Health Implications of Ageing. Profile of countries: demography data. London, 1990. [Unpublished]

34. LONGINO Jr., C.F. Who are the oldest americans? Gerontologist, 28: 515-23, 1988.

35. LOPEZ, A.D. \& HANADA, K. Mortality patterns and trends among the elderly in developed countries. Wld Hlth Statist. Quart., 35: 203-24, 1982.

36. MAGUIRE, P.A. et al. Elderly patients in acute medical wards: factors predicting length of stay in hospital. Brit. med.J., 292: $1251-3,1986$

37. MANTON, K.G. Changing concepts of morbidity and mortality in the elderly population. Milbank mem.F. Quart., 60: 183244, 1982.

38. MANTON, K.G. Mortality patterns in developed countries Comp. soc. Res. 7: 259-86, 1984.

39. MARTIN, L.G. The aging of Asia. J. Gerontol., 43: S99-113, 1988.

40. MARTINE, G. O mito da explosão demográfica. Ciênc. Hoje 9 (51): 28-35, 1989.

41. MARTINE, G. \& CARMARGO, L. Crescimento e distribuição da populaçãa brasileira. Rev. bras. Estud. Pop., 1 (1/2): $99-143,1984$.

42. MIDWINTER, E. An ageing world: the equivocal response. Ageing and Soc., 10: 221-8, 1990.

43. MIGUEL FILHO, E.C. et al. Aspectos psiquiátricos do idoso: um estudo no hospital geral. J. bras. Psiquiat., 38: 113-7, 1989.

44. MINISTÉRIO DA SAÚDE. Secretaria Nacional de Ações Básicas de Saúde. Estatística de mortalidade, Brasil: 1981 Brasília, Centro de Documentação do Ministério da Saúde, 1984

45. MINOIS, G., ed. History of old age: from antiquity to the rennaissance. Chicago, The University of Chicago Press. 1989.

46. MORTALIDADE por causas externas no Brasil. RADIS-Dados FIOCRUZ, Rio de Janeiro, 3 (8): 1985.

47. MYERS, G.C. \& NATHANSON, C.A. Ageing and the family. Wld Hith Statist. Quart., 35: 225-38, 1982.

48. NEUPERT, R.F. Nova projeção da população brasileira: hipóteses baseadas em informações recentes. In: Wong, L.L.R., org. Futuro da populaçāo brasileira: projeçōes, previsōes e técnicas. Embu, ABEP, 1987.

49. NEYSMITH, S.M. \& EDWARDS, J. Economic dependency in the 1980s: its impact on the third world elderly. Ageing and Soc., 4: 21-44, 1984

50. OLSHANSKY, S.J. Pursuing longevity: delay vs elimination of degenerative diseases. Amer. J. publ. Hlth, 75: 754-7, 1985.

51. OLSHANSKY, S.J. \& AULT, B. The fourth stage of the epidemiologic transition: the age of delayed degenerative diseases. Milbank mem. F. Quart. Hlth and Soc., 64: 35591, 1986.

52. OMRAN, A.R. The epidemiologic transition: a theory of epidemiology of population change, Milbank mem. $F$. Quart., 49: 509-38, 1971.

53. PADGETT, D. Aging minority women: issues in research and health policy. Women Hlth, 14: 213-25, 1988.

54. PAMPEL, F.C. \& WILLIAMSON, J.B. Age, class, politics and the welfare state. Cambridge, Cambridge University Press, 1989.

55. POPULAÇĀO brasileira no século XX: alguns dados. RADIS Dados FIOCRUZ, Rio de Janeiro, 1 (2) 1982. 
56. POSSAS. C.A. Epidemiologia e sociedade: heterogeneidade estrutural e saúde no Brasil. São Paulo, HUCITEC, 1989 (Saúde em Debate, $\mathrm{n}^{\circ} 24$ ).

57. RAMOS, L.R. \& GOIHMAN, S. Geographical stratification by socioeconomics status: methodology from a household survey with elderly people in S. Paulo, Brasil. Rev. Saude públ., S. Paulo, 23: 478-92, 1989.

58. RAMOS, L.R. et al. Envelhecimento populacional: uma realidade brasileira. Rev. Saúde públ., S. Paulo, 21: 211-24, 1987

59. RICE, D.P. \& FIELDMAN, J.J. Living longer in the USA demographic changes and health needs of the elderly. Milbank mem. F. Quart., 61: 362-96, 1983.

60. ROMANTUK, M. et al. An examination of prevalence. $J$ abnorm. Psychol, 92: 458-67, 1983.

61. ROSENWAIKE, I. A demographic portrait of the oldest old Milbank mem. F. Quart., 63: 187-205, 1985.

62. SANTOS, J.L.F. Demografia: estimativas e projeçōes. São Paulo, Faculdade de Arquitetura e Urbanismo da USP. 1978. (Prodeur, Cademos de Estudos e Pesquisa, 1)

63. SIEGEL, J.S. \& HOOVER, S.L. Demographic aspects of the health of the elderly to the year 2000 and beyond. Wld Hlth Statist. Quart., 32: 133-202, 1982.

64. TALLON Jr., J.R. \& BLOCK, R. Changing patterns of health insurance coverage: special concerns for women. Women Hlth, 14: 119-36, 1988.

65. THOMAS, L. Biomedical science and human health: the longrange prospect. Proc. Amer. Acad. Art and Sci., 106 (3): 1977.

66. TOUT, K. Aging in developing countries. Oxford, Oxford University Press, 1989.

67. TRAVASSOS-VERAS, C. Eqüidade e organização dos serviços de saúde: avaliação da assistência médico-hospitalar na cidade do Rio de Janeiro; Report of research. Washington, D.C., Pan American Health Organization, 1989.

68. UEDA, K. Demographic urbanization in Asia Countries. Tokyo, Southeast Asia Medical Information Center, SEAMIC, 1985.

69. UNITED NATIONS ORGANIZATION. Department of International Economic and Social Affairs. Periodical on Ageing: 1984. New York, v. 1, n. 1, 1985.

70. UNITED NATIONS ORGANIZATION. Department of Intemational Economic and Social Affairs. The world aging situation: strategies and policies; technical report. New York, 1985.

71. UNITED NATIONS ORGANIZATION. Department of
International Economical and Social Affairs. Demographic indicators of countries: estimates and projections assessed in 1980. New York, 1982.

72. UNITED NATIONS ORGANIZATION. Department of International Economical and Social Affairs. Patterns of urban and rural growth population studies. New York. 1980. (Serie 68).

73. VERAS, R.P. Avaliação multidimensional da população idosa. Cienc. e Cult., 39 (7): 90, 1987. [Apresentado à 39a Reunião Anual da SBPC].

74. VERAS, R.P. Considerações acerca de um jovem país que envelhece. Cad. Saúde públ., 4: 382-97, 1988.

75. VERAS, R.P. \& COUTINHO, E. Estudo de prevalência de depressão e síndrome cerebral orgânica na população de idosos, Brasil. Rev. Saúde públ.. S. Paulo, 25: 209-17, 1991.

76. VERAS, R.P. et al. População idosa no Rio de Janeiro (Brasil): estudo-piloto da confiabilidade e validação do segmento de saúde mental do questionário BOAS. Rev. Saúde públ., S. Paulo, 24: 156-63, 1990.

77. VERAS, R.P. et al. Proposta metodológica para inquérito domiciliar com populações idosas em um centro urbano do Estado do Rio de Janeiro (Brasil). Rev. Saúde públ., S. Paulo, 23: 429-38, 1989.

78. VERAS, R.P. et al. Crescimento da população idosa no Brasil: transformações e conseqüências na sociedade. Rev. Saúde públ., S. Paulo, 21: 225-33, 1987.

79. VERAS, R.P. et al. Pesquisando populações idosas - a importância do instrumento e o treinamento de equipe: uma contribuição metodológica. Rev. Saúde públ., S. Paulo, 22: $513-$ 8,1988 .

80. WARLICK, J.L. Why is poverty afer 65 a woman's problem. J. Gerontol. 40: 751-7, 1985.

81. WARNES, T. The elderly in less-developed world regions. Ageing and Soc., 6: 373-80, 1986.

82. WORLD BANK. Brazil adult health: adjusting to new challenges; Report n. 7807-BR. New York, 1989.

83. WORLD HEALTH ORGANIZATION. Scientific Group the Epidemiology of Aging, Geneva, 1983. The uses of epidemiology in the study of the elderly report. Geneva, 1984 (Technical Report Series, 706).

Received in 22/05/1991 Reviewed in 30/09/1991. Accepted in 14/10/1991. 